\title{
Longitudinal changes in bacterial community composition in river epilithic biofilms: influence of nutrients and organic matter
}

\author{
Yuki Kobayashi ${ }^{1}$, Chulgoo Kim ${ }^{1,3}$, Chikage Yoshimizu ${ }^{1,2}$, Ayato Kohzu ${ }^{1,2,4}$, \\ Ichiro Tayasu ${ }^{1}$, Toshi Nagata ${ }^{1,5, *}$ \\ ${ }^{1}$ Center for Ecological Research, Kyoto University, 2-509-3 Hirano, Otsu, Shiga 520-2113, Japan \\ ${ }^{2}$ Japan Science and Technology Agency, 4-1-8 Honcho, Kawaguchi, Saitama 332-0012, Japan \\ ${ }^{3}$ Present address: Center for Aquatic Ecosystem Restoration, Kangwon National University, Chun-Cheon, \\ Kangwon 200-701, Korea \\ ${ }^{4}$ Present address: National Institute for Environmental Studies, 16-2 Onogawa, Tsukuba, Ibaraki 305-8506, Japan \\ ${ }^{5}$ Present address: Ocean Research Institute, The University of Tokyo, 1-15-1 Minamidai, Nakano, Tokyo 164-8639, Japan
}

\begin{abstract}
Epilithic bacterial communities play a major role in biogeochemical cycles of rivers; however, distributional patterns and controls of epilithic communities remain unclear. The objective of the present study was to examine possible environmental factors that affect longitudinal distributional patterns of epilithic bacterial communities in 2 rivers (Yasu and Ado Rivers) draining the Lake Biwa basin, Japan. Phylogenetic analyses were conducted using denaturing gradient gel electrophoresis (DGGE) of 16S rRNA genes and fluorescence in situ hybridization (FISH) with oligonucleotide probes targeted to small subunit rRNA. Non-metric multidimensional scaling and canonical correspondence analysis of the DGGE profile indicated that a clear shift in community composition occurred at the middle reach of the Yasu River. This shift was most closely related to variation in the nitrogen stable isotope ratio $\left(\delta^{15} \mathrm{~N}\right)$ of epilithic materials (BIOENV analysis, $\rho_{\mathrm{w}}=0.512$ ), which is an indicator of the extent of anthropogenic nitrogen loading. The concentration of dissolved organic carbon (DOC) also affected community composition $\left(\rho_{\mathrm{w}}=0.510\right.$ for the combination of $\delta^{15} \mathrm{~N}$ and DOC). The longitudinal pattern of the DGGE profile was less evident in the Ado River. In both rivers, FISH results indicated that Alphaproteobacteria and Betaproteobacteria generally accounted for a large fraction ( 37 to $71 \%$ ) of total bacterial abundance, indicating that species and clones affiliated with a limited number of the major phylogenetic groups occupy diverse epilithic habitats. Our results are consistent with the hypothesis that nutrients and organic matter of anthropogenic origin are major determinants of epilithic bacterial community structure in rivers.
\end{abstract}

KEY WORDS: Bacterial community $\cdot$ Epilithic biofilm $\cdot$ River $\cdot$ Stable isotopes $\cdot$ Nutrients $\cdot$ Dissolved organic carbon · Denaturing gradient gel electrophoresis · Fluorescence in situ hybridization

\section{INTRODUCTION}

Epilithic biofilms covering the surface of stones and cobbles in river beds consist of diverse microbes (e.g. bacteria, archaea, heterotrophic protists, and photosynthetic algae) that play a major role in the regulation of food webs and biogeochemical cycles in rivers (Mulholland et al. 1995, Hall \& Meyer 1998). Evaluating distributional patterns and controls of epilithic bacterial communities is fundamentally important, because such information may help to improve our ability to predict the responses of river ecosystems to distur- 
bances and environmental changes that alter bacterial community structure. Rivers generally exhibit environmental gradients in physical variables along a longitudinal axis. These gradients often coincide with shifts in organic carbon sources and quality, eliciting a longitudinal transition in ecosystem properties and biotic communities (Vannote et al. 1980). However, whether lotic bacterial communities change in a predictable manner along general environmental gradients in rivers remains unclear (Leff 2000).

Anthropogenic inputs of organic matter and inorganic nutrients from urban and agricultural watersheds have increased in rivers worldwide during recent decades (Mulholland et al. 2008), leading to the enhancement of algal production (eutrophication) and changes in redox conditions (Wetzel 2001). Depending on the extent of the pollution and hydrological conditions, anthropogenic disturbances may create spatial patterns in the longitudinal distribution of dominant bacterial taxa in rivers. For example, Winter et al. (2007) demonstrated that the community composition of planktonic bacteria in the Danube River shifts over river stretches in response to changes in indices of anthropogenic eutrophication such as concentrations of nutrients and chlorophyll a ( $\mathrm{chl}$ a). Much less information is available about longitudinal variation in epilithic bacterial communities. Rubin \& Leff (2007) suggested that human-induced changes in concentrations and elemental ratios of nutrients in river water affect epilithic bacterial community structure in the Mahoning River (USA). Other studies have reported that epilithic bacterial community composition varies across reaches (Lyautey et al. 2003), seasons (Brümmer et al. 2000, 2003, Araya et al. 2003), or rivers (Brümmer et al. 2000, 2003, Fazi et al. 2005), presumably in response to nutrient inputs and the alteration of the biogeochemical state of the rivers. In addition to chemical factors, Anderson-Glenna et al. (2008) reported that seasonal and interannual changes in temperature significantly affect bacterial community composition. However, the geographical extent of data obtained in previous studies of epilithic communities is quite limited, which hampers thorough examinations of the patterns and controls of spatial variation in epilithic bacterial community composition along entire river stretches.

The objective of the present study was to examine potential environmental factors affecting the longitudinal distributional patterns of epilithic bacterial communities in 2 rivers (Yasu and Ado Rivers) draining the Lake Biwa basin, Japan. Phylogenetic analyses were conducted using denaturing gradient gel electrophoresis (DGGE) of 16S rRNA genes and fluorescence in situ hybridization (FISH) with oligonucleotide probes targeted to small subunit rRNA.

\section{MATERIALS AND METHODS}

Study sites and sampling of epilithic materials. On 28 and 29 May 2004, we collected samples in the Yasu River, which drains the basin of Lake Biwa, Japan (basin area $3848 \mathrm{~km}^{2}$ ) (Fig. 1). Among the 19 stations deployed in the main channel, 2 were close $(<400 \mathrm{~m})$ to the discharge site of major dams, including the Yasu (Stn Y4) and Ohzuchi dams (Stn Y6) (see Appendix 1, Table A1; Fig. 1). Four additional stations were located in major tributaries, near the points of confluence. The Yasu River drains a watershed $\left(387 \mathrm{~km}^{2}\right)$ in which the proportions of agricultural fields ( 0 to $31 \%$ ) and residential areas (0 to $10 \%$ ) tend to increase from the headstream to the river mouth and which houses an average population density of 320 people per $\mathrm{km}^{2}$ (land use and demographic analyses of the watersheds were conducted according to Kohzu et al. (2008a). On 27 and 28 September 2004, we collected samples in the Ado River (see Appendix 1, Table A2; Fig. 1). The Ado and its watershed $\left(306 \mathrm{~km}^{2}\right)$ are similar in size to the Yasu but are much less densely populated (25 people per $\mathrm{km}^{2}$ ) and more extensively covered by forest ( $96 \%$ of the entire watershed). Eleven stations were located in the main channel, and 3 additional stations were deployed in major tributaries. For both rivers, samples were collected during the period of baseline flow, i.e. the water level during sampling was within $\pm 0.3 \mathrm{~m}$ of the annual average water level (Ministry of Land, Infrastructure and Transportation, Japan; www1.river.go.jp/).

At each station, 4 cobbles with linear dimensions of 10 to $20 \mathrm{~cm}$ were sampled in the middle of the main channel (depth $=10$ to $30 \mathrm{~cm}$ ) with a relatively high flow rate (i.e. in a riffle). Although we did not examine types and chemistry of cobbles, the geological chart of the Lake Biwa basin (Geological Survey, Japan; riodb02.ibase.aist.go.jp) indicates that basal rocks of the Yasu River watershed mainly consist of sedimentary rocks throughout the main channel, although a granitic zone exists in the southern part of the watershed. In the Ado River, the dominant type of basal rocks is the accretionary complex (mainly sedimentary rocks) at the upstream site, whereas it is sedimentary at the downstream sites. Epilithic material from a $5 \times 5 \mathrm{~cm}$ area was scraped off the top surface of each cobble using a toothbrush and then suspended in autoclaved Milli-Q water. The samples collected from all 4 cobbles were combined into a sterile, high-density polyethylene tube (Falcon) and kept on ice and in the dark for later analysis in the laboratory.

On-site determination of physical and chemical variables. Water temperature, dissolved oxygen (DO), and specific conductivity (EC) were measured using a Model 85 SCOOT meter (YSI/Nanotech). Current velocity was measured by using flow meters: a Pocket Tachometer 

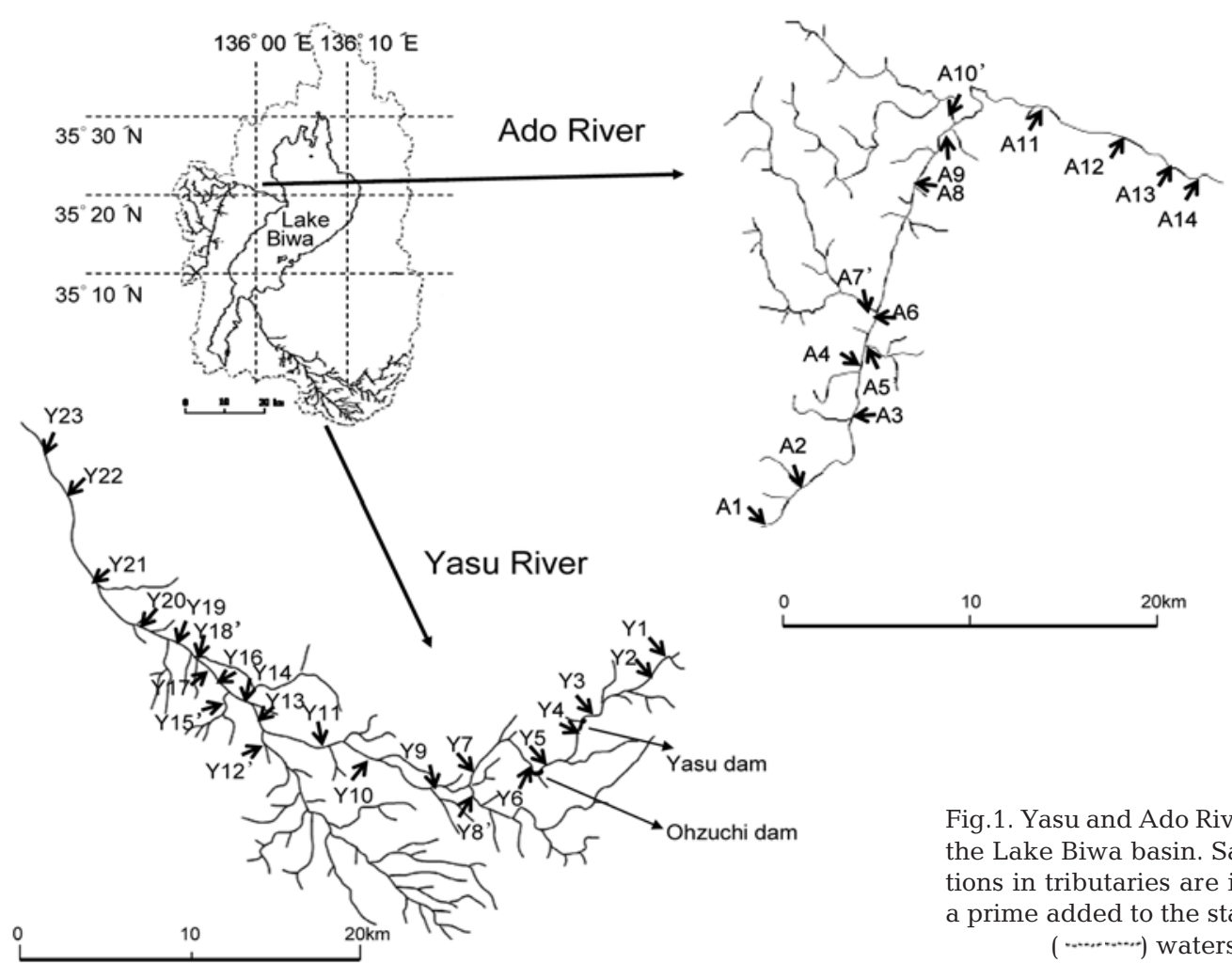

3631 (Yokogawa) in the Yasu, and a Stanley Model AEM1-D (Alec Electronics) in the Ado. $\mathrm{pH}$ and turbidity were determined with a $\mathrm{pH}$ meter (D-21ACT, Horiba) and a turbidometer (2100P, Hach), respectively.

Chemical analyses of river water. River water samples were filtered through $150 \mu \mathrm{m}$ meshed screen and contained in polyethylene tanks for the measurement of particulate constituents (see below). For the measurements of nutrients and dissolved organic carbon (DOC), sample waters were filtered through precombusted $\left(450^{\circ} \mathrm{C}, 5 \mathrm{~h}\right)$, acid-washed glass fiber filters (GF/F, Whatman). Filtrates were contained in acidwashed polystyrene (for nutrients) or polycarbonate (for DOC) bottles, kept cool, and brought back to the laboratory to be frozen for later analysis, except the analysis of ammonium concentration, which was conducted within $12 \mathrm{~h}$ (not frozen). Concentrations of nitrate, nitrite, and soluble reactive phosphorus (SRP) were determined with an auto-analyzer (AACS II, BRAN+LUEBBE) according to the manufacturer's manual. Ammonium concentration was determined fluorometrically with a TD700 fluorometer (Turner Designs) according to Holmes et al. (1999). Total dissolved nitrogen (TDN) and phosphorus (TDP) were measured by the wet oxidation method of Pujo-Pay \& Raimbault (1994). Concentrations of particulate organic carbon (POC) and nitrogen (PON) were measured using a CHN analyzer (PE-240II, Perkin Elmer), whereas particulate phosphorus (PP) was determined as SRP after wet oxidization. The sum of the dissolved and particulate constituents was regarded as the concentration of total nitrogen $(\mathrm{TN}=\mathrm{TDN}+\mathrm{PON})$ or total phosphorus (TP $=$ TDP + PP). Concentration of DOC was analyzed with a Shimadzu TOC 5000A total organic carbon analyzer according to Kim et al. (2006). Biological oxygen demand (BOD) was determined as the decrease of dissolved oxygen concentration (determined by the dissolved oxygen meter; YSI 5100, YSI/Nanotech) in river water contained in BOD bottles during the incubation period of $5 \mathrm{~d}$ at $20^{\circ} \mathrm{C}$.

Chemical analyses of epilithic materials. Epilithic materials were collected on precombusted GF/F filters. Concentrations of chlorophyll $a$ were determined fluorometrically after extraction with acetone (Wetzel \& Likens 2000). Concentrations of organic carbon $\left(\mathrm{POC}_{\mathrm{epi}}\right)$ and nitrogen $\left(\mathrm{PON}_{\mathrm{epi}}\right)$ and nitrogen isotopic compositions were determined using a continuous flow isotope ratio mass spectrometer (delta S, Finnigan) connected to the elemental analyzer (EA1108, Fisons) (Kohzu et al. 2008). The nitrogen stable isotope ratio was calculated in $\delta$ notation $\left(\delta^{15} \mathrm{~N}\right)$ as the difference in parts per thousand $(\delta)$ from the standard:

$$
\delta^{15} \mathrm{~N}=\left(\mathrm{R}_{\text {sample }} / \mathrm{R}_{\text {standard }}-1\right) \times 1000
$$

where $R_{\text {sample }}$ and $R_{\text {standard }}$ are ${ }^{15} \mathrm{~N} /{ }^{14} \mathrm{~N}$ values of the sample and standard (atmospheric nitrogen), respectively. 
DNA extraction. DNA contained in epilithic materials was extracted using the cetyl trimethyl ammonium bromide (CTAB) method (Murray \& Thompson 1980) with modifications. Sodium dodecyl sulfate (SDS; $1 \%$ ) and $0.2 \mathrm{mg} \mathrm{ml}^{-1}$ Proteinase $\mathrm{K}$ were added to the suspension of epilithic materials. After incubation at $65^{\circ} \mathrm{C}$ for $30 \mathrm{~min}$, $1.0 \mathrm{M} \mathrm{NaCl}$ and $1 \% \mathrm{CTAB}$ were added and incubated at $65^{\circ} \mathrm{C}$ for $30 \mathrm{~min}$. DNA was extracted using an equal amount of chloroform:isoamyl-alcohol (CIAA; 24:1). The aqueous phase was concentrated using a microconcentrator $\left(10000 \times g, 5 \mathrm{~min}, 4^{\circ} \mathrm{C}\right.$; Himac CF $15 \mathrm{D} 2$, Hitachi) to remove humic acids. After centrifugation $(10000 \times g$, $5 \mathrm{~min}, 4^{\circ} \mathrm{C}$ ), the supernatant was transferred to new tubes. DNA was precipitated by adding $2.5 \times$ the volume of $100 \%$ ethanol. To remove the ethanol, the DNA pellet was rinsed with $70 \%$ alcohol, dried, and suspended with Tris-EDTA (TE; $\mathrm{pH}$ 8.0). After RNase $\left(0.1 \mathrm{mg} \mathrm{ml}^{-1}\right)$ treatment at $37^{\circ} \mathrm{C}$ for $1 \mathrm{~h}$, the pellet was extracted with an equal amount of phenol:chloroform:isoamylalcohol (PCA; 25:24:1) and CIAA. After centrifugation $\left(10000 \times g, 5 \mathrm{~min}, 4^{\circ} \mathrm{C}\right)$, the aqueous phase was transferred to new tubes, to which $0.3 \mathrm{M}$ acetic acid and $2.5 \times$ the volume of $100 \%$ ethanol were added. After centrifugation $\left(10000 \times g, 5 \mathrm{~min}, 4^{\circ} \mathrm{C}\right)$, the ethanol was removed. The DNA pellet was resuspended in TE and then stored at $-30^{\circ} \mathrm{C}$ until analysis. The variable regions were amplified using the following primers (SigmaAldrich): GC-341F (5'-CGC CCG CCG CGC CCC GCG CCC GTC CCG CCG CCC CCG CCC GCC TAC GGG AGG CAG CAG-3'), and 907R (5'-CCG TCA ATT CCT TT G AGT TT-3') (Muyzer et al. 2004). The reaction mixture $(25 \mu \mathrm{l})$ contained $5 \mu \mathrm{l}$ of DNA extract in TE (10 to $20 \mathrm{ng}$ DNA, determined for selected samples), $2.5 \mu \mathrm{l}$ of PCR buffer, deoxynucleotide (Blend Taq kit, Toyobo), $3 \mu \mathrm{l}$ of $5 \mathrm{pmol}$ each of the universal primers (GC-341F and 907R, Sigma-Aldrich), and $0.2 \mu \mathrm{l}$ of $2.5 \mathrm{U}$ polymerase (Blend Taq kit, Toyobo). Thermocycling (iCycler, BioRad) was preceded by a 3 min heating step at $95^{\circ} \mathrm{C}$, followed by 32 cycles of denaturing at $95^{\circ} \mathrm{C}$ for $30 \mathrm{~s}$, annealing at $52^{\circ} \mathrm{C}$ for $30 \mathrm{~s}$, and extension at $72^{\circ} \mathrm{C}$ for $60 \mathrm{~s}$, with a final extension step of $8 \mathrm{~min}$ at $72^{\circ} \mathrm{C}$. The PCR product was quantified by agarose gel electrophoresis using a standard (molecular mass ruler, Takara Bio).

Denaturing gradient gel electrophoresis. DGGE was performed using the D-Code Universal Mutation Detection System (Bio-Rad) (Muyzer et al. 2004). The gel contained a gradient of denaturant ranging from 20 to $60 \%$ (100\% denaturant was $7 \mathrm{M}$ urea and $40 \%$ deionized formamide) in $1 \times$ TAE (40 mM Tris, $20 \mathrm{mM}$ acetic acid, $1 \mathrm{mM}$ EDTA). The PCR products (250 ng) containing loading buffer (Bio-Rad) were applied using markers (gel loading dye, DCode, Bio-Rad). DGGE was run at $50 \mathrm{~V}$ for $16 \mathrm{~h}$ at $60^{\circ} \mathrm{C}$. The gel was stained with $1 \times$ SYBR Gold (Molecular Probes) for detection (image acquisition with a CCD camera under UV illumination) and positioning (EDAS120 version 3.0, Kodak Digital Science) of DNA bands. Samples were run twice using a different order of sample loading. The bands detected in one of these runs $(10 \%$ of the total number of bands) were not included in the sequencing and the analysis of banding patterns to reduce errors associated with run-torun variations in the detection of bands.

DNA was extracted from the gel by incubation in TE at $4^{\circ} \mathrm{C}$ for $24 \mathrm{~h}$, reamplified using PCR (see above), run on DGGE, and then sequenced (see below). When sequencing was not successful, DGGE bands were cloned using the pGEM-T Vector System (Promega) before sequencing.

Sequencing and phylogenetic analysis. Sequencing of Yasu River samples was conducted using a DYEnamic direct cycle sequencing kit (Amersham Life Science) and a 373 DNA Sequencer (Applied Biosystems); sequencing of samples collected in the Ado River was outsourced (Macrogen). The sequencing primers were GC-341F and 907R (Muyzer et al. 2004). The sequence data were compared to those in GenBank using the BLAST function of the DNA Data Bank of Japan (DDBJ) server (www.ddbj.nig.ac.jp/Welcome-j.html), and the Classifier facility in the Ribosomal Database Project (rdp.cme.msu.edu/classifier/classifier.jsp). See Table 4 for GenBank accession numbers.

Determination of total prokaryotic abundance and fluorescence in situ hybridization analysis. Samples were fixed with $2 \%$ (final concentration) paraformaldehyde. The suspension of epilithic materials was mixed with $0.1 \%$ sodium pyrophosphate (1:9) and homogenized using Stomacher 80 (Biomaster Lab System, $10 \mathrm{~s}$ ) and an ultrasonic bath (Branson 5510, $1 \mathrm{~min})$; this procedure has been reported to yield the maximum cell abundance for counting biofilm samples (Buesing \& Gessner 2002). The homogenate was filtered onto $0.2 \mu \mathrm{m}$ polycarbonate membranes (Whatman).

Total prokaryotic abundance was counted by epifluorescence microscopy (BX61, Olympus) after staining with $10 \mathrm{\mu g} \mathrm{ml}^{-1}$ 4'6-diamino-2-phenylindole (DAPI) for 10 min. Bacterial community composition was determined using the FISH method with rRNAtargeted oligonucleotide probes (Nishimura \& Nagata 2007). The hybridization solution contained $2.5 \mu \mathrm{g}$ $\mathrm{ml}^{-1}$ probe, $0.9 \mathrm{~mol} \mathrm{l}^{-1} \mathrm{NaCl}, 20 \mathrm{mmol} \mathrm{l} \mathrm{l}^{-1}$ Tris- $\mathrm{HCl}$ (pH 7.2), $5 \mathrm{mmol} \mathrm{l}^{-1}$ EDTA, $0.01 \%$ SDS, and the concentration of formamide determined to achieve specificity for the bacterial groups targeted by the different probes (Table 1). Unlabeled competitors were added for probing Beta- and Gammaproteobacteria. All probes were commercially synthesized and labeled with Cy3 (Operon). After hybridization, the samples were transferred to a wash solution con- 
taining $20 \mathrm{mmol} \mathrm{l}^{-1}$ Tris- $\mathrm{HCl}(\mathrm{pH} 7.2), 5 \mathrm{mmol} \mathrm{l}^{-1}$ EDTA, $0.01 \%$ SDS, and the concentration of $\mathrm{NaCl}$ appropriate for each probe. The DAPI-positive cells and hybridized cells were counted manually under an epifluorescence microscope (Olympus BX50) equipped with optics described by Nishimura \& Nagata (2007). For each subgroup, 20 microscopic fields (1164.9 $\mathrm{\mu m}^{2}$ per field) were examined.

Statistical analyses of community patterns. The similarity of DGGE profiles derived from different bacterial communities was assessed using Bray-Curtis similarity (Quinn \& Keough 2002). Patterns in the sample-by-sample matrix of Bray-Curtis similarity were examined using non-metric multidimensional scaling (NMDS) (Quinn \& Keough 2002). The degree to which the plot matched the underlining similarity matrix was assessed using the Kruskal stress value formula. We performed 20 separate NMDS calculations for each plot using random starting configurations, and the best solution was that which produced the lowest stress. The BIOENV procedure (Clarke \& Warwick 2001) was used to define the suite of environmental variables that best explained the bacterial assemblage structure. BIOENV analyzes the rank correlation between Euclidean distance similarity matrices for environmental variables and the BrayCurtis similarity matrix computed for the DGGE fingerprint. These correlations were repeated for all possible combinations of the measured environmental variables (18 variables). The suite of environmental variables (or a single variable) that produced the highest correlation was considered the set that most accurately explained the community pattern. The above statistical analyses were conducted using PRIMER-E (version 6). NMDS and BIOENV have advantages owing to their lack of assumptions, but they also have their own weaknesses stemming from iteractive algorithms placing most weight on large distances (Clarke \& Warwick 2001). Thus, we performed canonical correspondence analysis (CCA) to examine the relationship between the DGGE fingerprint and environmental variables using CANOCO 4.5 (ter Braak \& Smilauer 2002).

\section{RESULTS}

\section{Environmental variables}

The physical, chemical, and microbiological parameters of the 2 rivers are summarized in Appendix 1, Tables A1 \& A2. In the Yasu River, high concentrations of total nitrogen (TN; maximum value of $103 \mu \mathrm{M}$ at Stn Y12'), nitrate (89 $\mu \mathrm{M}$, Stn Y12'), ammonium (3.9 $\mu \mathrm{M}$, Stn Y18'), total phosphorus (TP; $3.1 \mu \mathrm{M}$, Stn Y18'), and soluble reactive phosphorus (SRP; $1.4 \mu \mathrm{M}$, Stn Y18') in the middle to downstream reaches indicated nutrient pollution (Appendix 1, Table A1). The average concentrations of TP, SRP, and electric conductivity (EC) at the downstream sites were significantly higher $(\mathrm{p}<0.05)$ than those at the upstream sites (Table 2). Organic pollution in the middle reach was evident from significantly higher $(p<0.05)$ values of dissolved organic carbon (DOC) and biological oxygen demand $(\mathrm{BOD})$ in the downstream sites (mean $\pm \mathrm{SE}$; $144.6 \pm 9.6 \mu \mathrm{M}$ and $0.8 \pm 0.1 \mathrm{mg} \mathrm{l}^{-1}$ for DOC and BOD, respectively) than the upstream sites $(64.3 \pm 10.5 \mathrm{uM}$ and $0.4 \pm 0.1 \mathrm{mg} \mathrm{l}^{-1}$ ) (Table 2). The amounts of organic carbon, nitrogen, and chl a per unit surface area of cobbles in the downstream sites were significantly higher $(\mathrm{p}<0.05)$ than those in the upstream sites (Table 2). $\delta^{15} \mathrm{~N}$ of epilithic materials tended to increase downstream, with the lowest value at the upstream site $(-2.5$, Stn Y2) and the highest at the downstream sites (8.3, Stns Y17 and Y18'). These environmental variables along the entire Ado River were low and less variable compared to the data obtained in the Yasu River (Table 2 \& Appendix 1, Table A2).

\section{Spatial patterns in bacterial community composition revealed by DGGE and possible relationships with environmental factors}

Spatial patterns in bacterial community composition within and between the 2 rivers were examined using NMDS analysis of the DGGE fingerprints (an example of the DGGE gel is presented in Appendix 1, Fig. A1.

Table 1. Probes used to examine the abundance of major prokaryotic groups in epilithic biofilms

\begin{tabular}{|lcccc|}
\hline Phylogenetic group & Probe & Probe sequence & Formamide conc. (\%) & Source \\
\hline Eubacteria & Eub338 & GCT GCC TCC CGT AGG AGT & 30 & Amann et al. (1995) \\
Alphaproteobacteria & Alfa968 & GGT AAG GTT CTG CGC GTT & 30 & Glöckner et al. (1999) \\
Betaproteobacteria & Beta42 & GCC TTC CCA CTT CGT TT & 30 & Manz et al. (1992) \\
Gammaproteobacteria & Gam42a & GCC TTC CCA CAT CGT TT & 30 & Manz et al. (1992) \\
Cytophaga- Flavobacteria cluster & CF319 & TGG TCC GTG TCT CAG TAC & 35 & Manz et al. (1996) \\
Actinobacteria & HGC69a & TAT AGT TAC CAC CGC CGT & 20 & Glöckner et al. (2000) \\
Archaea & Arch915 & GTGCTC CCC CGC CAATTC CT & 20 & Amann et al. (1995) \\
\hline
\end{tabular}


We found 3 distinct clusters, each composed of specific geographical locations: the upstream reaches of the Yasu River (Cluster I), the downstream reaches of the Yasu River (Cluster II), and the Ado River (Cluster III, excluding the most upstream station, Stn A1) (Fig. 2). Because the goodness of fit of the stress value for the ordination with 2 dimensions was low (0.14), distances in the NMDS ordination reflect the magnitude of the dissimilarity in
DGGE patterns (Clarke \& Warwick 2001). The number of DGGE bands obtained for each station varied from 17 to 32 in the Yasu River and from 16 to 28 in the Ado River; in total, we detected 96 bands in the 2 rivers. Among these bands, $15(16 \%), 7(7 \%)$, and $21(22 \%)$ were unique to Clusters I, II, and III, respectively, and the remaining 53 bands ( $56 \%$ ) were common to 2 or 3 of the geographical clusters distinguished by NMDS.

Table 2. Summary of environmental variables in the Ado and Yasu Rivers. Variables are averaged for the upstream and downstream sites of each river in order to examine downward trends. Upstream sites of the Ado: Stns A1 to A7', $\mathrm{n}=7$; and the Yasu: (Stns Y1 to Y12', $\mathrm{n}=12$ ). Downstream sites of the Ado: Stns A8 to A14, $\mathrm{n}=7$; and the Yasu: Stns Y13 to Y23, $\mathrm{n}=11$. Student's $t$ test of the null hypothesis that the mean value of the upstream sites is equal to the mean value of the downstream sites; ns: not significant $(\mathrm{p}>0.05)$

\begin{tabular}{|c|c|c|c|c|}
\hline Variables & River & $\begin{array}{c}\text { Upstream } \\
\text { Mean } \pm \text { SE }\end{array}$ & $\begin{array}{c}\text { Downstream } \\
\text { Mean } \pm \text { SE }\end{array}$ & $\mathrm{p}$ \\
\hline \multicolumn{5}{|l|}{ Physical } \\
\hline Water temperature $\left({ }^{\circ} \mathrm{C}\right)$ & $\begin{array}{l}\text { Ado } \\
\text { Yasu }\end{array}$ & $\begin{array}{l}16.3 \pm 0.6 \\
18.1 \pm 1.0\end{array}$ & $\begin{array}{l}20.1 \pm 0.5 \\
22.2 \pm 0.6\end{array}$ & $\begin{array}{l}0.002 \\
0.003\end{array}$ \\
\hline Flow rate $\left(\mathrm{cm} \mathrm{s}^{-1}\right)$ & $\begin{array}{l}\text { Ado } \\
\text { Yasu }\end{array}$ & $\begin{array}{l}48.7 \pm 8.0 \\
49.8 \pm 9.8\end{array}$ & $\begin{array}{l}43.8 \pm 7.9 \\
35.9 \pm 7.0\end{array}$ & $\begin{array}{l}\text { ns } \\
\text { ns }\end{array}$ \\
\hline \multicolumn{5}{|l|}{ Chemical (water) } \\
\hline $\mathrm{pH}$ & $\begin{array}{l}\text { Ado } \\
\text { Yasu }\end{array}$ & $\begin{array}{l}7.3 \pm 0.2 \\
7.9 \pm 0.1\end{array}$ & $\begin{array}{l}7.4 \pm 0.0 \\
8.1 \pm 0.3\end{array}$ & $\begin{array}{l}\mathrm{ns} \\
\mathrm{ns}\end{array}$ \\
\hline $\mathrm{EC}\left(\mu \mathrm{S} \mathrm{cm}^{-1}\right)$ & $\begin{array}{l}\text { Ado } \\
\text { Yasu }\end{array}$ & $\begin{array}{l}45.2 \pm 6.3 \\
98.4 \pm 11.6\end{array}$ & $\begin{array}{c}58.1 \pm 0.8 \\
207.8 \pm 28.7\end{array}$ & $\begin{array}{c}\mathrm{ns} \\
0.001\end{array}$ \\
\hline Turbidity (NTU) & $\begin{array}{l}\text { Ado } \\
\text { Yasu }\end{array}$ & $\begin{array}{l}8.2 \pm 3.4 \\
2.1 \pm 0.5\end{array}$ & $\begin{array}{l}4.0 \pm 0.3 \\
3.1 \pm 0.5\end{array}$ & $\begin{array}{l}\mathrm{ns} \\
\mathrm{ns}\end{array}$ \\
\hline $\mathrm{TN}(\mu \mathrm{M})$ & $\begin{array}{l}\text { Ado } \\
\text { Yasu }\end{array}$ & $\begin{array}{l}47.5 \pm 3.0 \\
67.9 \pm 7.4\end{array}$ & $\begin{array}{l}66.6 \pm 4.7 \\
84.1 \pm 2.9\end{array}$ & $\begin{array}{c}0.005 \\
\mathrm{~ns}\end{array}$ \\
\hline $\mathrm{TP}(\mu \mathrm{M})$ & $\begin{array}{l}\text { Ado } \\
\text { Yasu }\end{array}$ & $\begin{array}{l}0.8 \pm 0.3 \\
0.3 \pm 0.1\end{array}$ & $\begin{array}{l}0.5 \pm 0.0 \\
1.2 \pm 0.2\end{array}$ & $\begin{array}{c}\mathrm{ns} \\
0.000\end{array}$ \\
\hline $\mathrm{BOD}\left(\mathrm{mg} \mathrm{l}^{-1}\right)$ & $\begin{array}{l}\text { Ado } \\
\text { Yasu }\end{array}$ & $\begin{array}{l}0.3 \pm 0.1 \\
0.4 \pm 0.1\end{array}$ & $\begin{array}{l}0.4 \pm 0.0 \\
0.8 \pm 0.1\end{array}$ & $\begin{array}{c}\mathrm{ns} \\
0.000\end{array}$ \\
\hline $\mathrm{DOC}(\mu \mathrm{M})$ & $\begin{array}{l}\text { Ado } \\
\text { Yasu }\end{array}$ & $\begin{array}{l}49.6 \pm 2.5 \\
64.3 \pm 10.5\end{array}$ & $\begin{array}{l}103.3 \pm 15.2 \\
144.6 \pm 9.6\end{array}$ & $\begin{array}{l}0.012 \\
0.000\end{array}$ \\
\hline Nitrate $(\mu \mathrm{M})$ & $\begin{array}{l}\text { Ado } \\
\text { Yasu }\end{array}$ & $\begin{array}{l}25.9 \pm 2.5 \\
61.1 \pm 6.9\end{array}$ & $\begin{array}{l}39.5 \pm 2.1 \\
60.0 \pm 3.3\end{array}$ & $\begin{array}{c}0.001 \\
\mathrm{~ns}\end{array}$ \\
\hline Ammonium $(\mu \mathrm{M})$ & $\begin{array}{l}\text { Ado } \\
\text { Yasu }\end{array}$ & $\begin{array}{l}0.3 \pm 0.1 \\
0.3 \pm 0.1\end{array}$ & $\begin{array}{l}0.4 \pm 0.1 \\
1.0 \pm 0.4\end{array}$ & $\begin{array}{l}\text { ns } \\
\text { ns }\end{array}$ \\
\hline $\operatorname{SRP}(\mu \mathrm{M})$ & $\begin{array}{l}\text { Ado } \\
\text { Yasu }\end{array}$ & $\begin{array}{l}0.4 \pm 0.1 \\
0.2 \pm 0.1\end{array}$ & $\begin{array}{l}0.3 \pm 0.0 \\
0.7 \pm 0.1\end{array}$ & $\begin{array}{c}\mathrm{ns} \\
0.000\end{array}$ \\
\hline \multicolumn{5}{|c|}{ Chemical and biological (epilithic) } \\
\hline $\begin{array}{l}\text { Bacterial abundance } \\
\left(\times 10^{6} \text { cells } \mathrm{cm}^{-2}\right)\end{array}$ & $\begin{array}{l}\text { Ado } \\
\text { Yasu }\end{array}$ & $\begin{array}{l}16.0 \pm 4.1 \\
25.0 \pm 6.1\end{array}$ & $\begin{array}{l}30.2 \pm 10.1 \\
68.6 \pm 9.1\end{array}$ & $\begin{array}{c}\mathrm{ns} \\
0.001\end{array}$ \\
\hline $\mathrm{Chl} \mathrm{a}\left(\mu \mathrm{g} \mathrm{cm}^{-2}\right)$ & $\begin{array}{l}\text { Ado } \\
\text { Yasu }\end{array}$ & $\begin{array}{l}1.4 \pm 0.4 \\
1.6 \pm 0.6\end{array}$ & $\begin{array}{l}3.2 \pm 0.8 \\
5.3 \pm 1.5\end{array}$ & $\begin{array}{c}\mathrm{ns} \\
0.033\end{array}$ \\
\hline $\mathrm{POC}_{\text {epi }}\left(\mathrm{mg} \mathrm{cm}^{-2}\right)$ & $\begin{array}{l}\text { Ado } \\
\text { Yasu }\end{array}$ & $\begin{array}{l}0.135 \pm 0.028 \\
0.199 \pm 0.055\end{array}$ & $\begin{array}{l}0.241 \pm 0.053 \\
0.453 \pm 0.074\end{array}$ & $\begin{array}{c}\mathrm{ns} \\
0.011\end{array}$ \\
\hline $\mathrm{PON}_{\mathrm{epi}}\left(\mathrm{mg} \mathrm{cm}^{-2}\right)$ & $\begin{array}{l}\text { Ado } \\
\text { Yasu }\end{array}$ & $\begin{array}{l}0.018 \pm 0.004 \\
0.027 \pm 0.007\end{array}$ & $\begin{array}{l}0.034 \pm 0.007 \\
0.066 \pm 0.012\end{array}$ & $\begin{array}{c}\mathrm{ns} \\
0.011\end{array}$ \\
\hline $\mathrm{C} / \mathrm{N}$ & $\begin{array}{l}\text { Ado } \\
\text { Yasu }\end{array}$ & $\begin{array}{l}9.3 \pm 0.8 \\
7.3 \pm 0.1\end{array}$ & $\begin{array}{l}8.5 \pm 0.6 \\
7.2 \pm 0.3\end{array}$ & $\begin{array}{l}\mathrm{ns} \\
\mathrm{ns}\end{array}$ \\
\hline$\delta^{15} \mathrm{~N}(\%)$ & $\begin{array}{l}\text { Ado } \\
\text { Yasu }\end{array}$ & $\begin{array}{l}0.4 \pm 0.5 \\
1.1 \pm 0.7\end{array}$ & $\begin{array}{l}1.9 \pm 0.8 \\
6.5 \pm 0.3\end{array}$ & $\begin{array}{c}\mathrm{ns} \\
0.000\end{array}$ \\
\hline
\end{tabular}




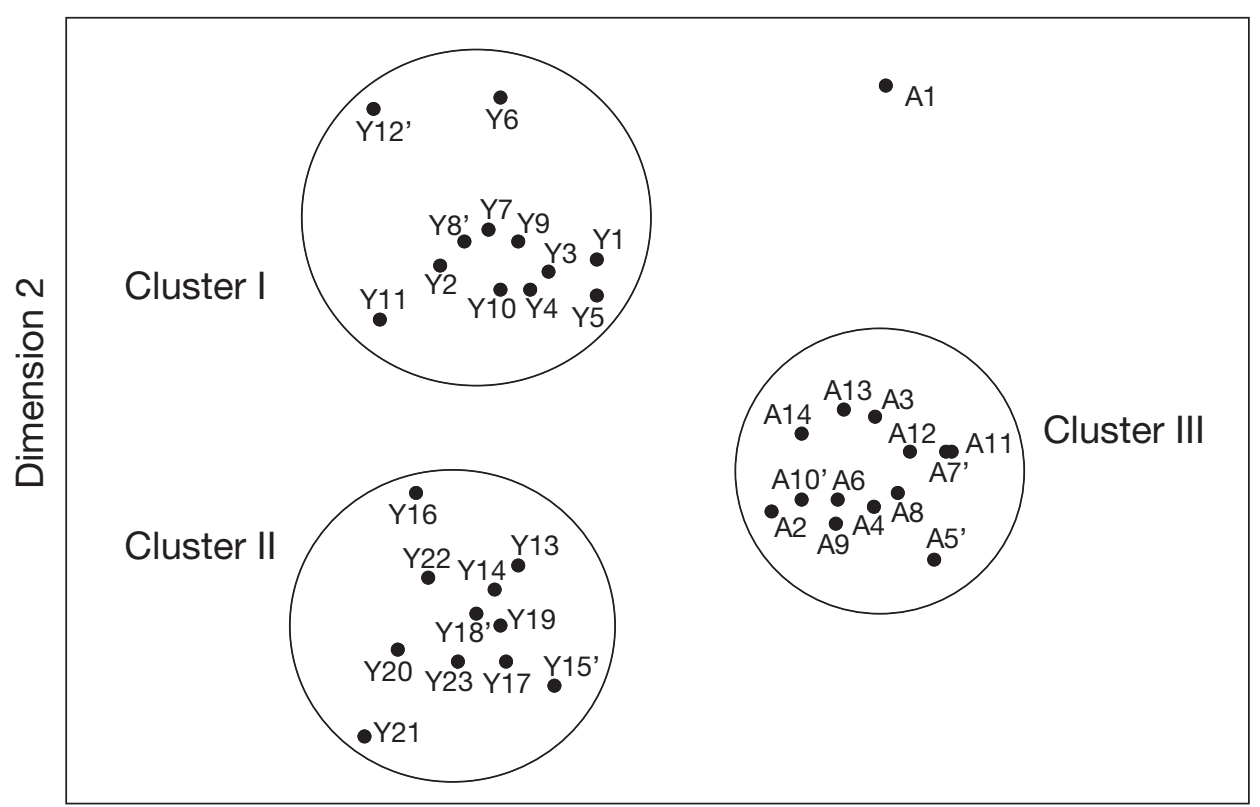

\section{Dimension 1}

Fig.2. Non-metric multidimensional scaling analysis of the DGGE fingerprint (stress value $=0.14$ ). Three clusters corresponded to geographical locations: Cluster I: upstream sites of the Yasu River (Stns Y1 to Y12'); Cluster II: downstream sites of the Yasu River (Stns Y13 to Y23); and Cluster III: Ado River (Stns A2 to A14, A1 excluded). See Fig. 1 for station locations

The BIOENV procedure (Clarke \& Warwick 2001) was used to examine possible relationships between bacterial community composition and environmental variables (see Table 2). Within the entire dataset obtained from the Yasu and Ado Rivers, the highest correlation ( $\rho_{\mathrm{w}}=0.479$ ) between bacterial composition and environmental variables was found for the combination of EC, TP, and nitrate (Table 3). The same analysis was conducted for the Yasu, and the highest correlation ( $\rho_{\mathrm{w}}=0.512$ ) was found for the $\delta^{15} \mathrm{~N}$ of epilithic materials (Table 3 ). The second highest correlation ( $\left.\rho_{\mathrm{w}}=0.510\right)$ was obtained for the combination of DOC and $\delta^{15} \mathrm{~N}$ (Table 3 ).

We also conducted CCA (ter Braak \& Smilauer 2002) to explore spatial patterns in community structure and their possible relationships with environmental variables (Fig. 3). Among 18 variables determined (Table 2), 9 were selected by forward selection, i.e. variables were added until model improvement failed $(p<0.05)$. The selected variables, from strong to weak statistical significance (in parentheses), judged by Monte-Carlo permutation tests, were: nitrate $(\mathrm{p}=0.002), \delta^{15} \mathrm{~N}(\mathrm{p}=0.002), \mathrm{pH}(\mathrm{p}=0.002)$, temperature $(\mathrm{p}=0.004), \mathrm{TP}(\mathrm{p}=0.004), \mathrm{SRP}(\mathrm{p}=0.010), \mathrm{EC}(\mathrm{p}=$ $0.014), T N(p=0.04)$, and DOC $(p=0.048)$. The sum of all eigenvalues $\left(\Sigma \lambda_{\mathrm{i}}\right)$ was 3.156 , whereas the sum of all canonical eigenvalues ( $\left.\Sigma \lambda_{\text {canonical }}\right)$ was 1.366 . The variance in DGGE (ribotypes) explained by the environmental variables $\left(\Sigma \lambda_{\text {canonical }} / \Sigma \lambda_{i} \times 100\right)$ was $43 \%$. These results are generally consistent with the results obtained from the BIOENV analysis conducted for the entire dataset (Table 3), except that temperature was selected in the CCA but not in the BIOENV analysis. The relative positioning of the sampling sites in the ordination plot indicated the presence of 3 geographical clusters, which agrees well with that in the NMDS plot (Fig. 2).

Table 3. Results of the BIOENV analysis defining a subset of environmental variables that best explains the community structure. The analysis was conducted for the entire dataset obtained from the Yasu and Ado Rivers as well as those obtained only in the Yasu. A series of a single or a combination of environmental variables is presented according to the rank (low $=1$, high $=5$ ) of the magnitude of correlation between the community and environmental data matrices. Eighteen environmental variables (see Table 2) were used. Bac: bacterial abundance in the epilithon

\begin{tabular}{|lccc|}
\hline Sites & Rank & $\begin{array}{c}\text { Correlation } \\
\left(\rho_{\mathrm{w}}\right)\end{array}$ & Variables \\
\hline Yasu + Ado & 1 & 0.479 & $\mathrm{EC}, \mathrm{TP}$, Nitrate \\
& 2 & 0.468 & $\mathrm{pH}, \mathrm{EC}, \mathrm{TP}$, Nitrate \\
& 3 & 0.467 & $\mathrm{EC}, \mathrm{TP}$ \\
& 4 & 0.458 & $\mathrm{pH}, \mathrm{EC}, \delta^{15} \mathrm{~N}, \mathrm{TP}, \mathrm{Nitrate}$ \\
Yasu only & 5 & 0.457 & $\mathrm{pH}, \delta^{15} \mathrm{~N}, \mathrm{Nitrate}$ \\
& 1 & 0.512 & $\delta^{15} \mathrm{~N}$ \\
& 2 & 0.510 & $\delta^{15} \mathrm{~N}, \mathrm{DOC}$ \\
& 3 & 0.508 & $\mathrm{Bac}, \delta^{15} \mathrm{~N}, \mathrm{DOC}$ \\
& 4 & 0.500 & $\mathrm{Bac}, \delta^{15} \mathrm{~N}, \mathrm{BOD}, \mathrm{DOC}$ \\
& 5 & 0.498 & $\mathrm{Bac}, \mathrm{BOD}, \mathrm{DOC}$ \\
\hline
\end{tabular}




\section{Phylogenetic analyses of DGGE bands and biogeography of ribotypes}

We successfully sequenced 25 DGGE bands. Among these, 20 ribotypes were matched to particular sequences of identified bacteria at a level of $97 \%$ similarity, all of which were assigned to major phylogenetic groups based on the most similar sequences in the database (Table 4). The most frequently sequenced phylogenetic groups were Cyanobacteria (32\%), followed by Betaproteobacteria (28\%), Bacteroidetes (20\%), Alphaproteobacteria (12\%), and Gammaproteobacteria (8\%). Plastids were not detected.

Some ribotypes were detected at multiple sites covering the entire stretches of the Yasu and Ado Rivers. These ribotypes were affiliated with Alphaproteobacteria (ID 1, 2 and 3; see Table 4 for the ID description), Betaproteobacteria (ID 4, 7 \& 9), Gammaproteobacteria (ID 12), Bacteroidetes (ID 15), and Cyanobacteria (ID 20 \& 25). Other ribotypes displayed more restricted distributions: 8 ribotypes were found only in the Ado River (Betaproteobacteria, ID 5; Bacteroidetes, ID $13 \&$ 16; Cyanobacteria, ID 19, 21, 22, $23 \&$ 24),

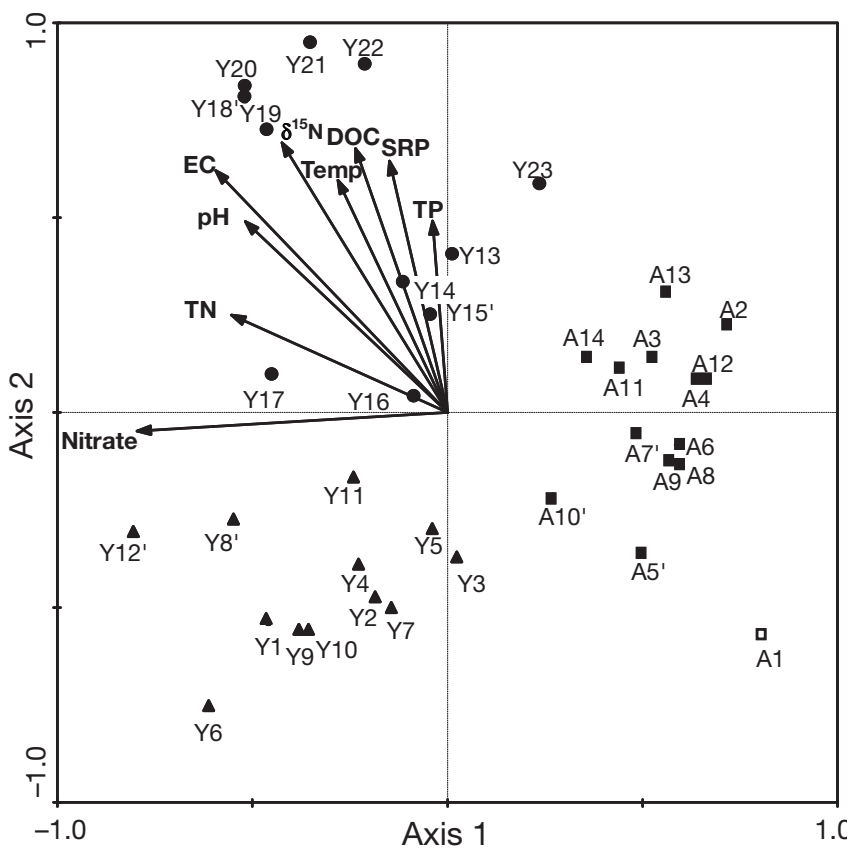

Fig. 3. CCA ordination of bacterial communities in relation to measured environmental variables (high-lighted in bold). The length and angle of the vectors relative to the axes indicate correlations of sampling sites with each environmental variable selected by forward selection. The relative positioning of the sampling sites is constrained by the set of environmental variables. $\mathbf{\Delta}$ : Cluster $\mathrm{I}_{i} \boldsymbol{\bullet}$ : Cluster $\mathrm{II}_{i}$ 口: Cluster III; $\square$ : Stn A1. Eigenvalues for Axes 1 and 2 are 0.410 and 0.329 , respectively. The percentage of variance of ribotype data explained by Axes 1 and 2 are 13.0 and $9.6 \%$, respectively, whereas the corresponding values of the ribotype-environment relationship are 30.0 and $22.2 \%$ whereas 3 ribotypes were detected only in the Yasu River (Betaproteobacteria, ID 6 \& 8; Gammaproteobacteria, ID 11). One ribotype affiliated with Bacteroidetes (ID 14, closest affiliation with $96 \%$ similarity is uncultured Flavobacterium sp.) was only detected at the less polluted sites, i.e. the sites upstream of the Yasu and Ado Rivers.

\section{Spatial distribution of the major phylogenetic groups of prokaryotes and correlations with environmental variables}

Prokaryotic community structure at the level of the domain or major phylogenetic group (division or subdivision) was analyzed using FISH (Fig. 4). For 11 out of 37 samples, we failed to obtain data because of high background fluorescence. Community structure did not exhibit systematic variation among the geographical clusters distinguished by NMDS and CCA of the DGGE bands (i.e. Clusters I, II, and III). The relative abundances of individual phylogenetic groups averaged for each cluster did not differ significantly among clusters (ANOVA, p > 0.05) (Table 5). The mean relative abundance of the domain Bacteria (Eub338 positive cells) was $78 \pm 6 \%$, but only $1 \pm 1 \%$ for Archaea (Arch915 positive cells). Among Bacteria, Alphaproteobacteria were the most abundant group (34 $\pm 6 \%$ ), followed by Betaproteobacteria (20 $\pm 6 \%$ ), Gammaproteobacteria $(8 \pm 8 \%)$, and the Cytophaga-Flavobacteria cluster ( $\mathrm{CF}$ cluster; $7 \pm 5 \%$ ). Actinobacteria were less abundant $(<3 \%)$ at all examined sites. The relative abundance of each group averaged for each river is listed in Table 6.

Gammaproteobacteria were abundant at sites located just downstream of the dams, with relative abundances of 30 and $37 \%$ at Stn Y4 (downstream of the Yasu dam) and Stn Y6 (Ohzuchi dam), respectively (Fig. 4a). The relative abundance of the CF cluster varied greatly (2 to $26 \%$ ); higher values (>10\%) occurred in the upstream reach of the Ado River (Stns A2, A4 and A6) (Fig. 4b). Results of simple correlation analyses indicated that only the following variables were significantly correlated: Alphaproteobacteria and total bacterial abundance in the epilithon $(\mathrm{r}=0.49, \mathrm{p}=0.01, \mathrm{n}=26)$, Betaproteobacteria and $\mathrm{PON}_{\mathrm{epi}}(\mathrm{r}=0.54, \mathrm{p}=0.004, \mathrm{n}=26)$, and Gammaproteobacteria and $\mathrm{POC}_{\mathrm{epi}}(\mathrm{r}=0.42, \mathrm{p}=0.035, \mathrm{n}=26)$.

\section{DISCUSSION}

We investigated broad-scale distribution patterns of epilithic bacterial communities and correlated these with extensive measurement of environmental vari- 


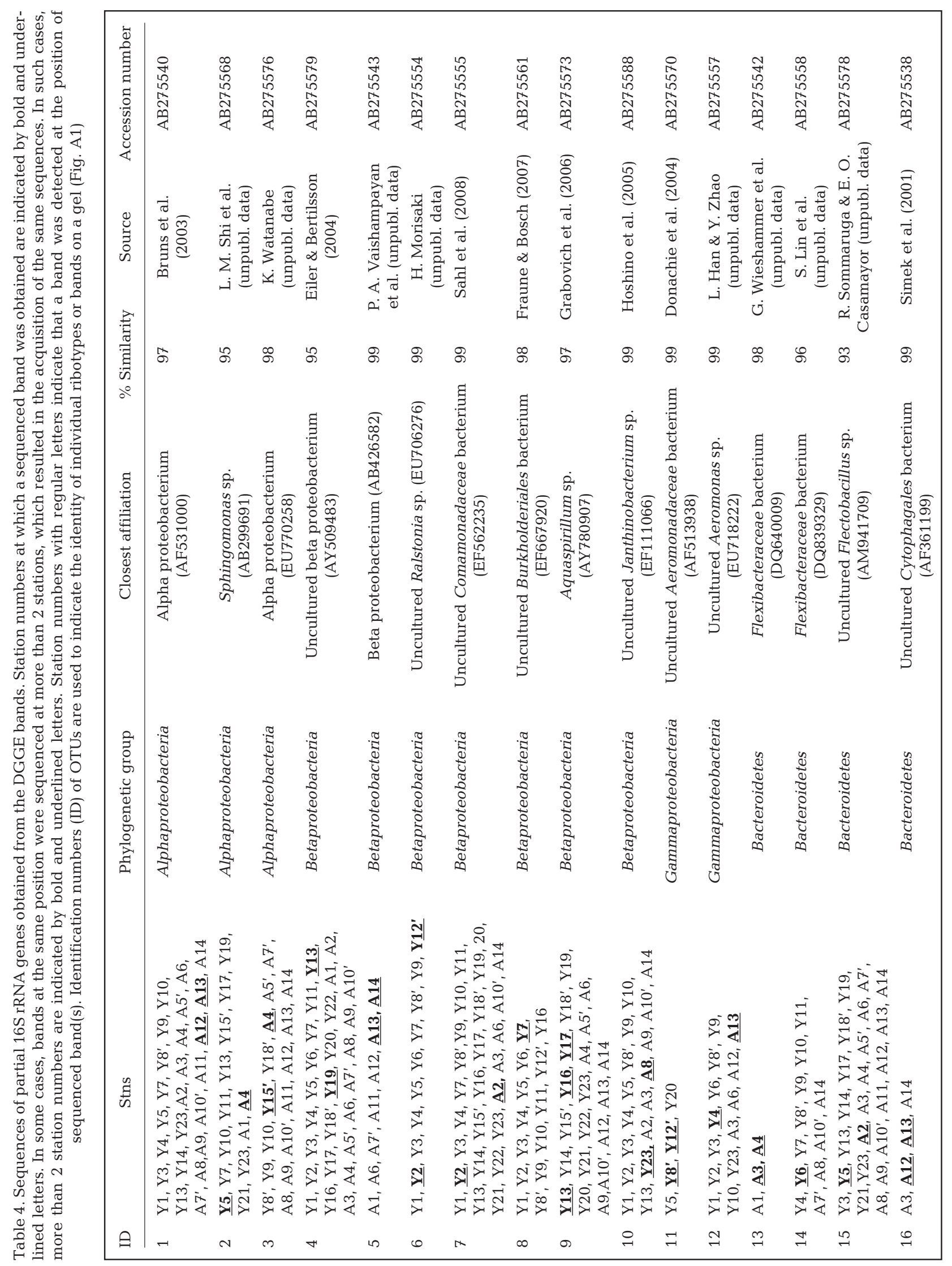




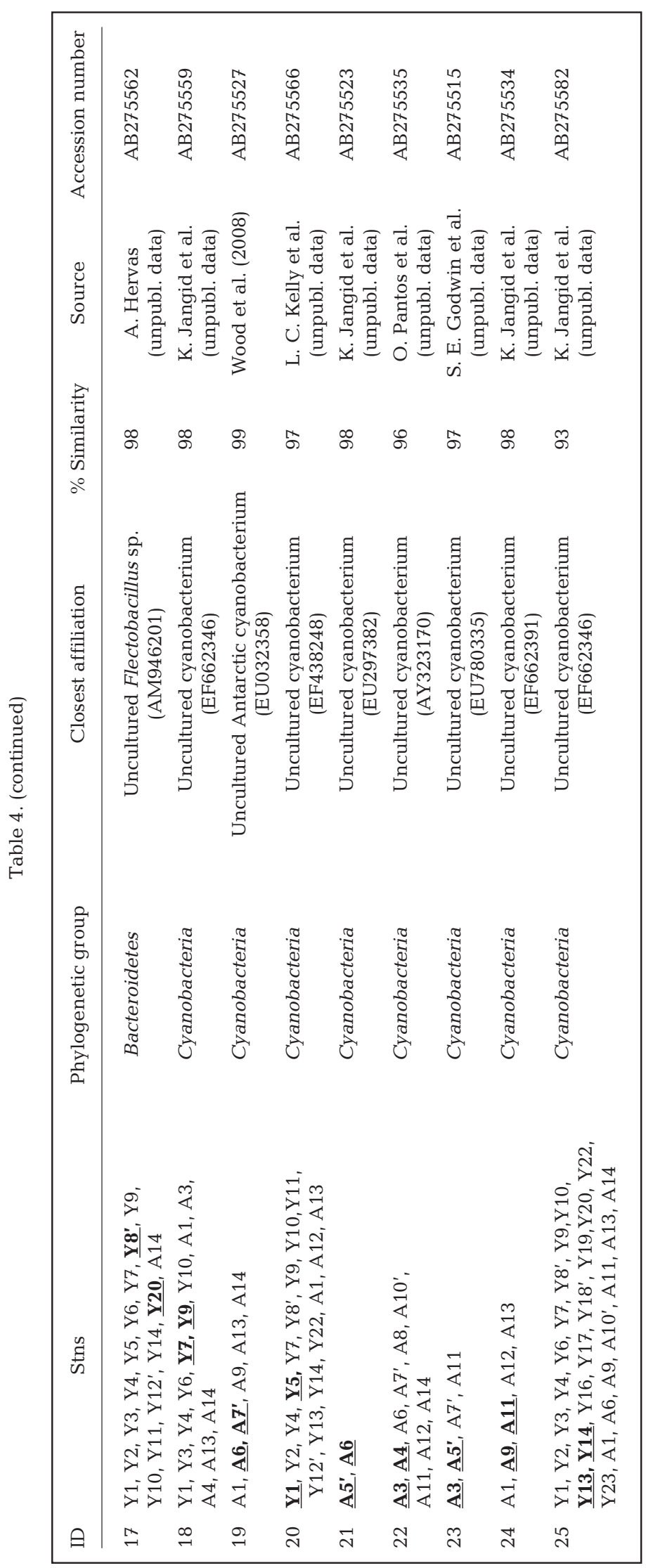

ables. The examination of geographical patterns in bacterial community composition can lead to hypotheses regarding the dominant mechanisms by which bacterial communities are structured (Fierer et al. 2007, Beier et al. 2008). However, we were limited in our ability to fully capture the complexity of the controls of epilithic communities due to local conditions, including hydrodynamics of the surface boundary layer (Besemer et al. 2007) and biotic interactions (Sutherland et al. 2004, Huws et al. 2005). Mineral composition and texture of the cobble surfaces might also affect epilithic communities (Gleeson et al. 2006), although changing patterns in the community structure could not be accounted for by geological settings of the investigated region, i.e. bed rocks are mainly sedimentary throughout the regions (see 'Materials and methods'). Furthermore, our small sample sizes may not fully represent whole epilithic communities in individual river reaches. Despite these limitations, the PCR-DGGE fingerprints of epilithic bacterial communities revealed that the Yasu River can be divided into 2 stretches, composed of upstream (Stns Y1 to Y12'; Cluster I) and downstream (Stns Y13 to Y23; Cluster II) sites (Figs. $2 \& 3$ ). This clear shift in epilithic bacterial community composition at the middle reach of the river appears to be related to anthropogenic inputs of nutrients and organic matter from the watershed. In support of this hypothesis, the BIOENV results suggest a link between bacterial community composition and the $\delta^{15} \mathrm{~N}$ of epilithic materials $\left(\rho_{\mathrm{w}}=0.512\right)$ (Table $3)$. The $\delta^{15} \mathrm{~N}$ of epilithic materials can serve as an indicator of the extent of sewage-derived nitrogen loading, because nitrate derived from sewage effluent is enriched with ${ }^{15} \mathrm{~N}$ (Kendall et al. 2007), and this isotopic signal is transferred to primary producers such as epilithic algae through the utilization of nitrate (Cole et al. 2004, Kohzu et al. 2008a,b), although isotopic fractionation associated with denitrification in rivers may also result in ${ }^{15} \mathrm{~N}$-enrichment of nitrate (Kendall et al. 2007). The correspondence in the locations of discontinuity (between Stns Y12' and Y13) in both bacterial community composition and increases in DOC concentrations also suggests that the organic matter loading from the watershed plays a role in shaping bacterial community structure. The combination of $\delta^{15} \mathrm{~N}$ and DOC $\left(\rho_{\mathrm{w}}=0.510\right)$ clearly contributed to spatial variation in bacterial community composition in the Yasu River.

In contrast, we failed to detect any systematic, spatial patterns in community shifts along river stretches in the Ado River, with the exception that community composition at the most upstream site (Stn A1) differed from that at other sites in the NMDS (Fig. 2). Sampling from the Yasu and Ado Rivers was conducted during different seasons (Yasu in May and Ado 
in September), which may in part explain the observed differences in community patterns between the 2 rivers. Previous studies have reported that bacterial community composition in epilithic biofilms exhibits seasonal variations, presumably in response to changes in physical conditions such as temperature (Hullar et al. 2006), and flow rate and substrate condi- tions (Olapade \& Leff 2006). Differences in nutrient and organic matter loading from the watershed may also explain the variation in bacterial community structure between the 2 rivers. This hypothesis is consistent with the BIOENV results indicating that, for the entire dataset, indicators of anthropogenic effects on water chemistry (EC, TP, nitrate), rather than physical variables (temperature and flow rate), were selected as the set of environmental parameters most closely related to bacterial community composition (Table 3).

Epilithic bacterial community composition, as revealed by FISH, varied little among the different geographical clusters distinguished by the NMDS and CCA of DGGE fingerprints. Regardless of site, epilithic bacteria were dominated by Alphaproteobacteria and Betaproteobacteria: these 2 groups accounted for nearly half of the total prokaryotic cells. The differences observed between DGGE and FISH results may reflect differences in methodology. Community composition revealed by DGGE may include errors due to potential biases associated with PCR (Polz \& Cavanaugh 1998), which can result in underor over-representation of particular phylogenetic groups of bacteria (Castle \& Kirchman 2004, Webster \& Negri 2006). However, our data on nucleotide sequences of the DGGE bands indicated that Alphaproteobacteria and Betaproteobacteria accounted for a large fraction $(40 \%)$ of the total number of sequenced bands, which was consistent with the results obtained by FISH. DGGE fingerprints may also be biased by the inclusion of plastid DNA extracted from epilithic algae. However, this effect was probably minor in our samples, because plastid DNA was not detected among the sequenced ribotypes. Thus, the differences in community patterns obtained by DGGE and FISH likely reflect differences in the taxonomic resolution of community analyses: spatial variability in community composition was much more pronounced at the finer phylogenetic level (as revealed by DGGE) than at the level of the major phylogenetic group (as revealed by FISH).

Previous studies have found that Alphaproteobacteria and Betaproteobacteria often dominate epilithic communities in river systems, including the Mahoning (Olapade \& Leff 2004, 2006, Rubin \& Leff 2007), Elbe (Brümmer et al. 2000), Spittelwasser (Brümmer et al. 2000), Albegna (Fazi et al. 2005), Fiora (Fazi et al. 2005), and Kanzaki (Araya et al. 2003)

Fig. 4. Longitudinal variations of the relative abundance of different phylogenetic groups of prokaryotes in epilithic biofilms of the (a) Yasu and (b) Ado Rivers. Arrows indicate positions of the dams. YD: Yasu dam; OD: Ohzuchi dam; Alpha: Alphaproteobacteria; Beta: Betaproteobacteria; Gamma: Gammaproteobacteria; CF: Cytophaga-Flavobacteria cluster; Actino: Actinobacteria; Arch: Archaea. See Fig. 1 for location of sample stations given above bars 
Table 5. Summary of the relative abundances of different phylogenetic groups of prokaryotes including those affiliated with Bacteria (Eub), Alphaproteobacteria (Alpha), Betaproteobacteria (Beta), Gammaproteobacteria (Gamma), the Cytophaga-Flavobacteria cluster (CF), Actinobacteria (Actino), and Archaea (Arch). The mean \pm SE (range) are given for the data obtained in each geographical cluster (Cluster I, II, or III) distinguished by the non-metric multidimensional scaling of the denaturing gradient gel electrophoresis patterns (Fig. 2). Corresponding values for the entire sampling site are also presented (Yasu + Ado). ANOVA indicated that, for all the phylogenetic groups examined, there was no significant ( $p>0.05)$ difference in mean values of the relative abundance among different geographical clusters

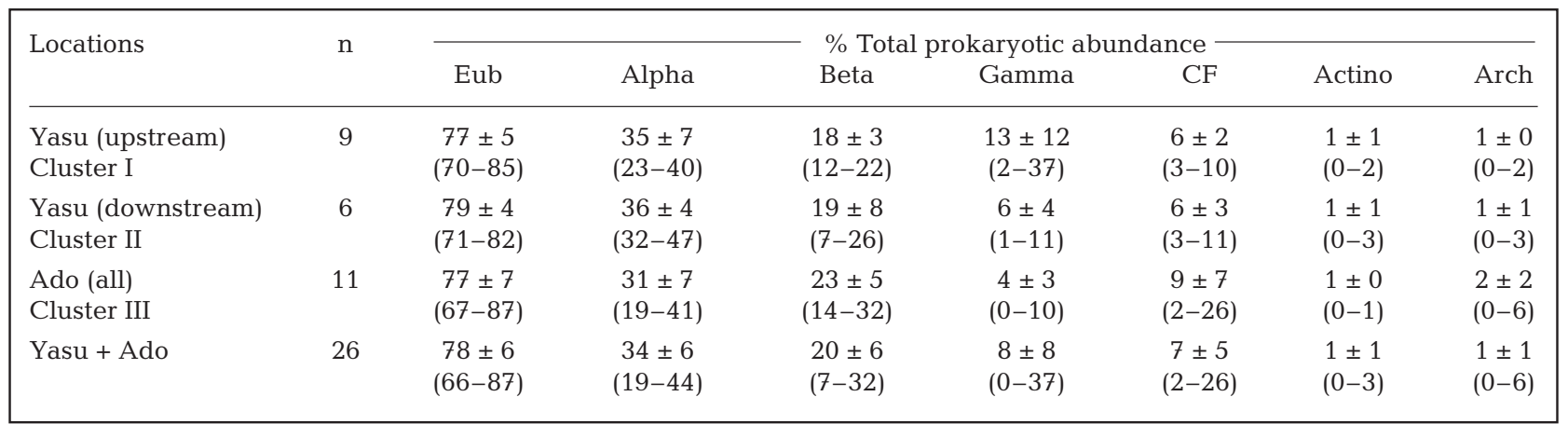

Rivers, although high abundances of other groups, including the CF cluster (O'Sullivan et al. 2002, Rubin \& Leff 2007) and Actinobacteria (O'Sullivan et al. 2002) have also been reported (Table 6). In Italian rivers, Fazi et al. (2005) found that Alphaproteobacteria tend to become more abundant than Betaproteobacteria in epilithic biofilms in riffles, whereas the reverse was true for samples collected in pools of the same rivers. Our data confirm and supplement these previous results, which suggests that species and clones affiliated with a small number of the major phylogenetic groups, i.e. Alphaproteobacteria and Betaproteobacteria, can occupy a wide range of epilithic habitats. This assertion is consistent with the results of Brümmer et al. (2003), who found that Betaproteobacteria in biofilms of polluted rivers in Germany consisted of various clones exhibiting characteristic distributional patterns, most likely as a reflection of species- or clonespecific adaptations to environmental conditions.

Although community composition determined by FISH at the level of the broad phylogenetic group was less variable than that revealed by DGGE, the distribution of Gammaproteobacteria, which were highly abundant ( $>30 \%$ of total prokaryotes) at 2 sites downstream of the dams of the Yasu River, was noteworthy. Gammaproteobacteria consist of a dynamic group of bacteria (e.g. Vibrionales) characterized by multiple genotypes (Polz et al. 2006), fast growth (Yokokawa et al. 2004), adaptation to organically polluted waters (Watkins \& Cabelli 1985), and active production of extracellular polymers that provide the matrices of biofilms (Hammer \& Bassler 2003). Although these features might explain the high abundance of Gammaproteobacteria, future studies must identify which environmental conditions favor the occurrence of this bacterial group in epilithic communities downstream of dams. The CF cluster also displayed large variability in relative abundance ( 2 to $26 \%$ ). Although the relative abundance of this phylogenetic bacterial group was not significantly correlated with any of the environmental variables studied, the $\mathrm{CF}$ cluster tended to be abundant $(>20 \%)$ in the upstream reaches of the Ado River. Given that this group competitively uses high molecular weight organic carbon, including cellulose (Kirchman 2002), the observed pattern may reflect allochthonous organic carbon loading from the forested watershed of the Ado River.

In conclusion, bacterial community composition revealed by PCR-DGGE in epilithic biofilms of the Yasu River displayed a longitudinal pattern, possibly in response to anthropogenic nutrient- and organic matter-loading from the watershed. These results suggest that epilithic bacterial community composition can serve as a biotic indicator of pollution and eutrophication in rivers. FISH results revealed that Alphaproteobacteria and Betaproteobacteria dominated epilithic bacterial communities across both study reaches and rivers, indicating that species and clones affiliated with a limited number of major phylogenetic groups occupy diverse epilithic habitats, including both polluted and less polluted environments.

Acknowledgements. This study was supported by the Basic Research Program (CREST) of the Japan Science and Technology Agency and the 21st Century COE program of Kyoto University (A14). We thank T. Yokokawa and Y. Nishimura for suggestions regarding FISH analysis, S. Okunishi for information regarding the DGGE method, and K. Yoshiyama for helpful comments on statistical analyses. Thanks are also due to T. Yokokawa, Y. Nishimura, T. Miki, C. Motegi, F. Rassoulzadegan and other members of the Aquatic Microbial Ecology seminar of CER, Kyoto University, for stimulative discussions. I. Shimizu and J. Takabayashi allowed us to use their lab facilities. 


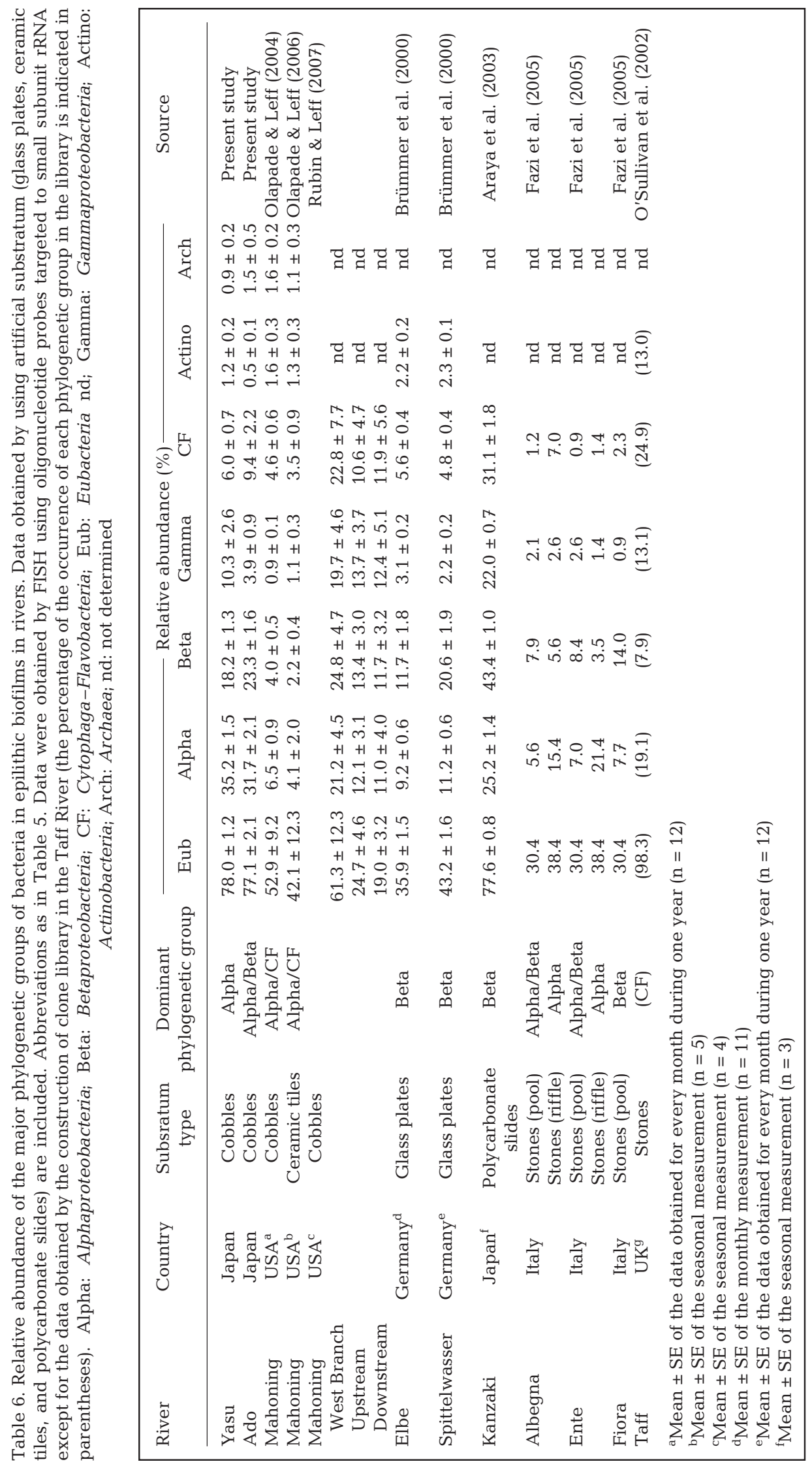




\section{LITERATURE CITED}

Amann RI, Ludwig W, Schleifer KH (1995) Phylogenetic indentification and in situ detection of individual microbial cells without cultivation. Microbiol Rev 59:143-169

Anderson-Glenna MJ, Bakkestuen V, Clipson NJW (2008) Spatial and temporal variability in epilithic biofilm bacterial communities along an upland river gradient. FEMS Microbiol Ecol 64:407-418

Araya R, Tani K, Takagi T, Yamaguchi N, Nasu M (2003) Bacterial activity and community composition in stream water and biofilm from an urban river determined by fluorescent in situ hybridization and DGGE analysis. FEMS Microbiol Ecol 43:111-119

Beier S, Witzel KP, Marxsen J (2008) Bacterial community composition in central European running waters examined by temperature gradient gel electrophoresis and sequence analysis of 16S rRNA genes. Appl Environ Microbiol 74:188-199

Besemer K, Singer G, Limberger R, Chlup AK and others (2007) Biophysical controls on community succession in stream biofilms. Appl Environ Microbiol 73:4966-4974

Brümmer IHM, Fehr W, Wagner-Döbler I (2000) Biofilm community structure in polluted rivers: abundance of dominant phylogenetic groups over a complete annual cycle. Appl Environ Microbiol 66:3078-3082

Brümmer IHM, Felske A, Wagner-Döbler I (2003) Diversity and seasonal variability of ,-proteobacteria in biofilms of polluted rivers: analysis by temperature gradient gel electrophoresis and cloning. Appl Environ Microbiol 69: 4463-4473

Bruns A, Hoffelner H, Overmann J (2003) A novel approach for high throughput cultivation assays and the isolation of planktonic bacteria. FEMS Microbiol Ecol 45:161-171

Buesing N, Gessner MO (2002) Comparison of detachment procedures for direct counts of bacteria associated with sediment particles, plant litter and epiphytic biofilms. Aquat Microb Ecol 27:29-36

Castle D, Kirchman DL (2004) Composition of estuarine bacterial communities assessed by denaturing gradient gel electrophoresis and fluorescence in situ hybridization. Limnol Oceanogr Methods 2:303-314

Clarke KR, Warwick RM (2001) Change in marine communities: an approach to statistical analysis and interpretation, 2nd edn. Primer-E, Plymouth Marine Laboratory, Plymouth

Cole ML, Valiela I, Kroeger KD, Tomasky GL and others (2004) Assessment of a $\delta^{15} \mathrm{~N}$ isotopic method to indicate anthropogenic eutrophication in aquatic ecosystems. J Environ Qual 33:124-132

Donachie SP, Hou S, Lee KS, Riley CW and others (2004) The Hawaiian archipelago: a microbial diversity hotspot. Microb Ecol 48:509-520

Eiler A, Bertilsson S (2004) Composition of freshwater bacterial communities associated with cyanobacterial blooms in four Swedish lakes. Environ Microbiol 6:1228-1243

Fazi S, Amalfitano S, Pernthaler J, Puddu A (2005) Bacterial communities associated with benthic organic matter in headwater stream microhabitats. Environ Microbiol $7: 1633-1640$

Fierer N, Morse JL, Berthrong ST, Bernhardt ES, Jackson RB (2007) Environmental controls on the landscape-scale biogeography of stream bacterial communities. Ecology 88:2162-2173

Fraune S, Bosch TCG (2007) Long-term maintenance of species-specific bacterial microbiota in the basal metazoan Hydra. Proc Natl Acad Sci USA 104:13146-13151
Gleeson DB, Kennedy NM, Clipson N, Melville K, Gadd GM, McDermott FP (2006) Characterization of bacterial community structure on a weathered pegmatitic granite. Microb Ecol 51:526-534

> Glöckner FO, Fuchs BM, Amann R (1999) Bacterioplankton compositions of lakes and oceans: a first comparison based on fluorescence in situ hybridization. Appl Environ Microbiol 65:3721-3726

Glöckner FO, Zaichikov E, Belkova N, Denissova L, Pernthaler J, Pernthaler A, Amann R (2000) Comparative 16S rRNA analysis of lake bacterioplankton reveals globally distributed phylogenetic clusters including an abundant group of actinobacteria. Appl Environ Microbiol 66: 5053-5065

Grabovich M, Gavrish E, Kuever J, Lysenko AM, Podkopaeva D, Dubinina G (2006) Proposal of Giesbergeria voronezhensis gen. nov., sp. nov. and G. kuznetsovii sp. nov. and reclassification of [Aquaspirillum] anulus, [A.] sinuosum and [A.] giesbergeri as Giesbergeria anulus comb. nov., G. sinuosa comb. nov. and G. giesbergeri comb. nov., and [Aquaspirillum] metamorphum and [A.] psychrophilum as Simplicispira metamorpha gen. nov., comb. nov. and $S$. psychrophila comb. nov. Int J Syst Evol Microbiol 56:569-576

Hall RO, Meyer JL (1998) The trophic significance of bacteria in a detritus-based stream food web. Ecology 79: 1995-2012

Hammer BK, Bassler BL (2003) Quorum sensing controls biofilm formation in Vibrio cholerae. Mol Microbiol 50:101-114

> Holmes RM, Aminot A, Kérouel R, Hooker BA, Peterson BJ (1999) A simple and precise method for measuring ammonium in marine and freshwater ecosystems. Can J Fish Aquat Sci 56:1801-1808

Hoshino T, Terahara T, Tsuneda S, Hirata A, Inamori Y (2005) Molecular analysis of microbial population transition associated with the start of denitrification in a wastewater treatment process. J Appl Microbiol 99:1165-1175

> Hullar MA, Kaplan LA, Stahl DA (2006) Recurring seasonal dynamics of microbial communities in stream habitats. Appl Environ Microbiol 72:713-722

Huws SA, McBain AJ, Gilbert P (2005) Protozoan grazing and its impact upon population dynamics in biofilm communities. J Appl Microbiol 98:238-244

Kendall C, Elliot EM, Wankel SD (2007) Tracing anthropogenic inputs of nitrogen to ecosystems. In: Michener R, Lajtha K (eds) Stable isotopes in ecology and environmental science, 2nd edn. Blackwell Scientific, Oxford, p 375-449

Kim C, Nishimura Y, Nagata T (2006) Role of dissolved organic matter in hypolimnetic mineralization of carbon and nitrogen in a large, monomictic lake. Limnol Oceanogr 51:70-78

Kirchman DL (2002) The ecology of Cytophaga-Flavobacteria in aquatic environments. FEMS Microbiol Ecol 39:91-100

> Kohzu A, Tayasu I, Yoshimizu C, Maruyama A and others (2008a) Nitrogen-stable isotopic signatures of basal food items, primary consumers and omnivores in rivers with different levels of human impact. Ecol Res 24(1):127-136

Kohzu A, Miyajima T, Tayasu I, Yoshimizu C and others (2008b) Use of stable nitrogen isotope signatures of riparian macrophytes as an indicator of anthropogenic $\mathrm{N}$ inputs to river ecosystems. Environ Sci Technol 42(21):7837-7841

Leff LG (2000) Longitudinal changes in microbial assemblages of the Ogeechee River. Freshw Biol 43:605-615

> Lyautey E, Teissier S, Charcosset JY, Rols JL, Garabétian F (2003) Bacterial diversity of epilithic biofilm assemblages 
of an anthropised river section, assessed by DGGE analysis of a 16S rDNA fragment. Aquat Microb Ecol 33:217-224

Manz W, Amann R, Ludwig W, Wagner M, Schleifer KH (1992) Phylogenetic oligodeoxynucleotide probes for the major subclasses of proteobacteria: problems and solutions. Syst Appl Microbiol 15:593-600

> Manz W, Amann R, Ludwig W, Vancanneyt M, Schleifer KH (1996) Application of a suite of 16S rRNA-specific oligonucleotide probes designed to investigate bacteria of the phylum Cytophaga-Flavobacter-Bacteroides in the natural environment. Microbiology 142:1097-1106

Mulholland PJ, Marzolf ER, Hendricks SP, Wilkerson RV, Baybayan AK (1995) Longitudinal patterns of nutrient cycling and periphyton characteristics in streams: a test of upstream-downstream linkage. J N Am Benthol Soc 14:357-370

Mulholland PJ, Helton AM, Poole GC, Hall RO and others (2008) Stream denitrification across biomes and its response to anthropogenic nitrate loading. Nature 452: 202-206

Murray MG, Thompson WF (1980) Rapid isolation of high molecular weight plant DNA. Nucleic Acids Res 8: 4321-4325

Muyzer G, Brinkhoff T, Nübel U, Santegoeds C, Schäfer H, Wawer C (2004) Denaturing gradient gel electrophoresis (DGGE) in microbial ecology. In: Kowalchuk GA, de Bruijn FJ, Head IM, Akkermans ADL, van Elsas JD (eds) Molecular microbial ecology manual, 2nd edn. Kluwer Academic Publishers, Dordrecht, p743-770

Nishimura Y, Nagata T (2007) Alphaproteobacterial dominance in a large mesotrophic lake (Lake Biwa, Japan). Aquat Microb Ecol 48:231-240

Olapade OA, Leff LG (2004) Seasonal dynamics of bacterial assemblages in epilithic biofilms in a northeastern Ohio stream. J N Am Benthol Soc 23:686-700

Olapade OA, Leff LG (2006) Influence of dissolved organic matter and inorganic nutrients on the biofilm bacterial community on artificial substrates in a northeastern Ohio, USA, stream. Can J Microbiol 52:540-549

O'Sullivan LA, Weightman AJ, Fry JC (2002) New degenerate Cytophaga-Flexibacter-Bacteroides-specific 16S ribosomal DNA-targeted oligonucleotide probes reveal high bacterial diversity in River Taff epilithon. Appl Environ Microbiol 68:201-210

Polz MF, Cavanaugh CM (1998) Bias in template-to-product ratios in multitemplate PCR. Appl Environ Microbiol 64:3724-3730

Polz MF, Hunt DE, Preheim SP, Weinreich DM (2006) Patterns and mechanisms of genetic and phenotypic differentiation in marine microbes. Philos Trans R Soc Lond B 361:
2009-2021

Pujo-Pay M, Raimbault P (1994) Improvement of the wet-oxidation procedure for simultaneous determination of particulate organic nitrogen and phosphorus collected on filters. Mar Ecol Prog Ser 105:203-207

Quinn GP, Keough MJ (2002) Experimental design and data analysis for biologists. Cambridge University Press, Cambridge

Rubin MA, Leff LG (2007) Nutrients and other abiotic factors affecting bacterial communities in an Ohio river (USA). Microb Ecol 54:374-383

Sahl JW, Schmidt R, Swanner ED, Mandernack KW and others (2008) Subsurface microbial diversity in deep-graniticfracture water in Colorado. Appl Environ Microbiol 74:143-152

Simek K, Pernthaler J, Weinbauer MG, Hornák K and others (2001) Changes in bacterial community composition and dynamics and viral mortality rates associated with enhanced flagellate grazing in a mesoeutrophic reservoir. Appl Environ Microbiol 67:2723-2733

Sutherland IW, Hughes KA, Skillman LC, Tait K (2004) The interaction of phage and biofilms. FEMS Microbiol Lett 232:1-6

ter Braak CJF, Smilauer P (2002) Canoco reference manual and CanocoDraw for Windows user's guide: software for canonical community ordination (version 4.5). Microcomputer Power, Ithaca, NY

Vannote RL, Minshall GW, Cummins KW, Sedell JR, Cushing CE (1980) The river continuum concept. Can J Fish Aquat Sci 37:130-137

Watkins WD, Cabelli VJ (1985) Effect of fecal pollution on Vibrio parahaemolyticus densities in an estuarine environment. Appl Environ Microbiol 49:1307-1313

Webster NS, Negri AP (2006) Site-specific variation in Antarctic marine biofilms established on artificial surfaces. Environ Microbiol 8:1177-1190

Wetzel RG (2001) Limnology: lake and river ecosystems, 3rd edn. Academic Press, San Diego, p 151-168

Wetzel RG, Likens GE (2000) Limnological analysis, 3rd edn. Springer-Verlag, Berlin

- Winter C, Hein T, Kavka G, Mach RL, Farnleitner AH (2007) Longitudinal changes in the bacterial community composition of the Danube River: a whole-river approach. Appl Environ Microbiol 73:421-431

- Wood SA, Rueckert A, Cowan DA, Cary SC (2008) Sources of edaphic cyanobacterial diversity in the dry valleys of eastern Antarctica. ISME J 2:308-320

Yokokawa T, Nagata T, Cottrell MT, Kirchman DL (2004) Growth rate of the major phylogenetic bacterial groups in the Delaware estuary. Limnol Oceanogr 49:1620-1629 
Appendix 1. Summaries of geographic, demographic and environmental variables of the Yasu and Ado rivers, and banding of the 16S rRNA gene amplicons on a DGGE gel for samples collected in the Ado River

Table A1. Geographic and demographic features and environmental variables at the sampling stations of the Yasu River. WT: water temperature; Flow: water flow rate; EC: electric conductivity; Chl a: chlorophyll $a$ in epilithon; POC epi $_{\text {: }}$ particulate organic carbon in epilithon; $\mathrm{PON}_{\text {epi }}$ : particulate organic nitrogen in epilithon; TN: total nitrogen in river water; TP: total phosphorus in river water; BOD: biological oxygen demand in river water; DOC: dissolved organic carbon in river water; SRP: soluble reactive phosphorus in river water

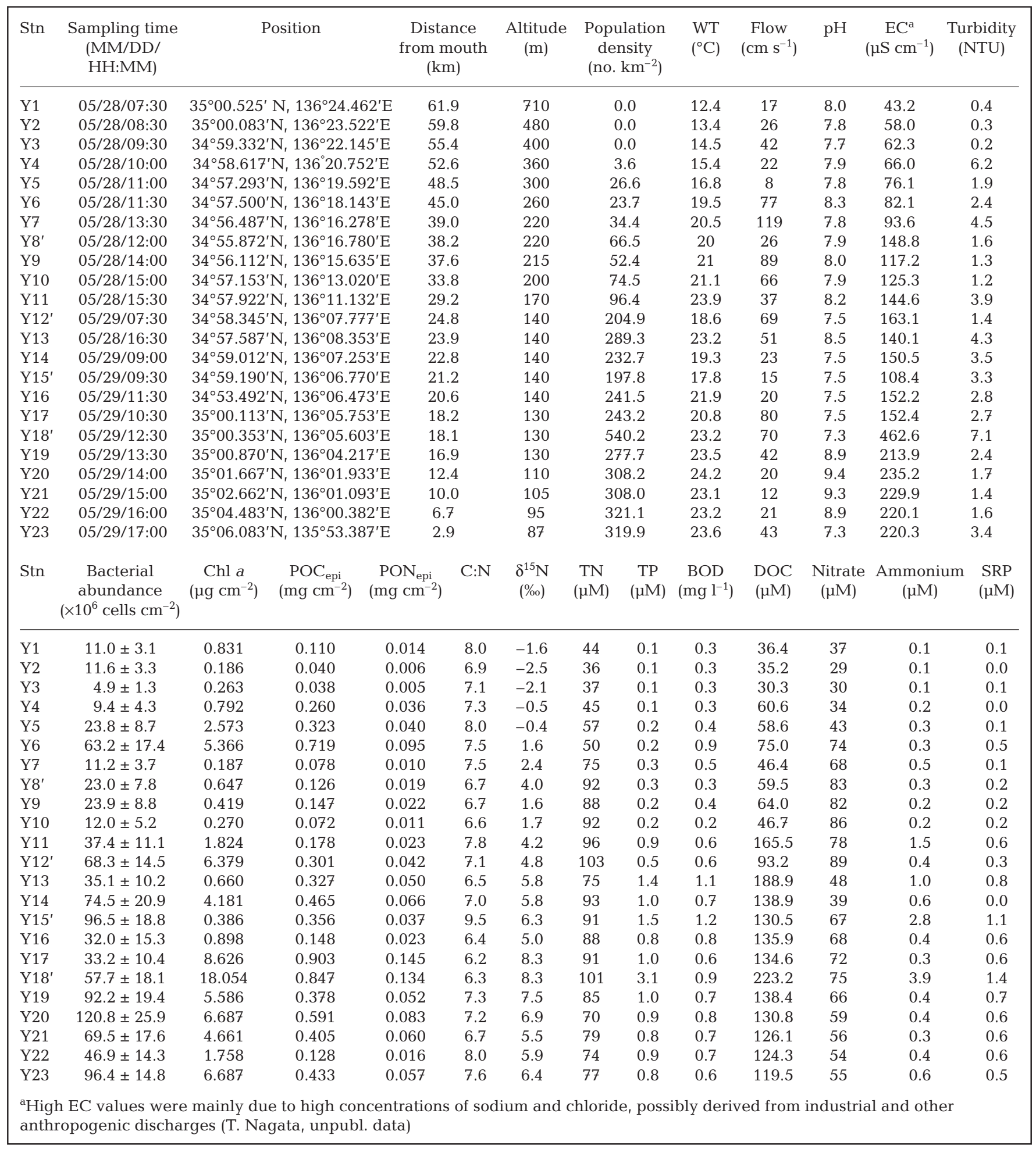


Table A2. Geographic and demographic features and environmental variables at the sampling stations of the Ado River. Abbreviations as in Table A1

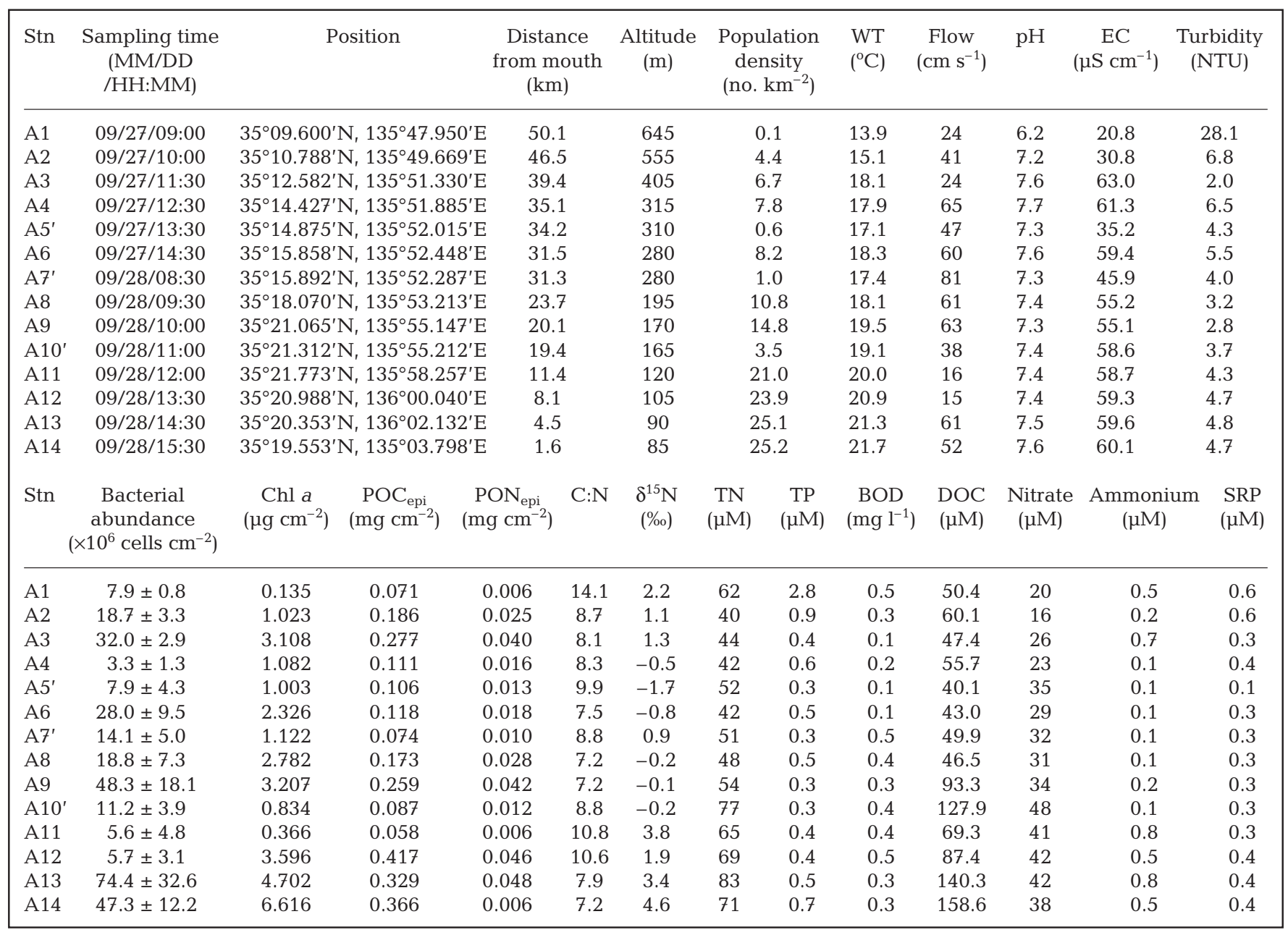




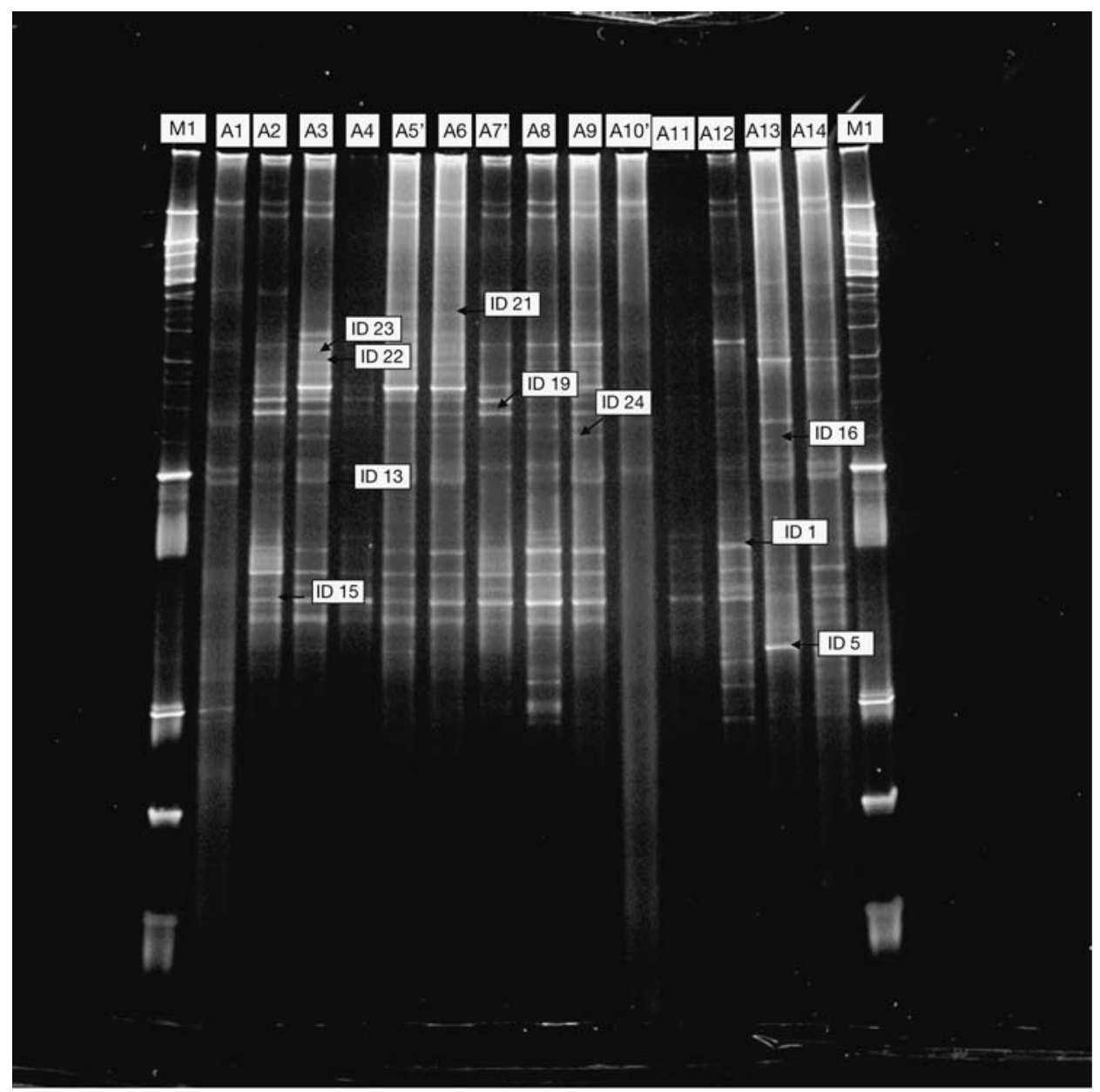

Fig. A1. Example of the DGGE gel (samples are from the Ado River). M1: marker; A1-A14: sampling stations; $(\rightarrow)$ bands applied for sequencing. ID numbers as in Table 4

Editorial responsibility: Rutger de Wit Montpellier, France
Submitted: May 15, 2008; Accepted: October 8, 2008

Proofs received from author(s): January 23, 2009 